\title{
Deception in Conversation: The Study of Prince Andew's Inteview About Jeffrey Epstein Sexual Allegations
}

\author{
Sofista Lilla Saferia \\ 1 Univesitas Negeri Surabaya, Indonesia \\ ${ }^{1}$ sofista.1702015048@mhs.unesa.ac.id
}

\begin{abstract}
The objectives of this study are unfolding deception and find deception markers with Linguistics features in Prince Andrew's BBC Interview. This study used document analysis for collecting data and qualitative approach, and the data are gathered from the transcript in an official BBC interview video from YouTube. There are few stages in analyzing the data. First, altering the data in the form of dialogue and categorizing violation of Grice's Cooperate Principles found in the data, then analyzing the context within the violation with Bachenko's theory of deception signals. The result of this study indicates that Prince Andrewshows a deeper relationship and more involvement with Jeffrey Epstein than what he was trying to say in the interview.
\end{abstract}

Keywords: deception, linguistics, interview

\section{INTRODUCTION}

This study will analyze the depth of Prince Andrew BBC interview. In his interview he talked about his relationship with convicted sex offender and pedophilia, Jeffrey Epstein. In the summer of 2019, Jeffrey Epstein was convicted by federal prosecutors on one count of sexual exploitation of a minor and one count of conspiracy to conduct sex trafficking. Epstein was denied bail after pleading not guilty to the crimes, and was later found dead in his Manhattan jail cell. Suicide was reported to be the cause of the death.Although Epstein's high-profile social circle remained in the headlines even despite his death. In fact, in both parties, Epstein's friends included not only politicians, but it also included royalty. At that point, Queen Elizabeth's son, Prince Andrew, reportedly had close connections to Epstein.The Duke of York has made multiple claims about Epstein in recent months, and he documented an interview at Buckingham Palace in November about their relationship with reporter Emily Maitlis.Even though, the Prince was denying any accusation on his relationship with Jeffrey Epstein, the interview was not taken well on the public when it released. Many analyses conducted by several professionals like Human Behavior Analysts and Psychologists disclose amount of deception in the interview. The Queen's son willingly retreated from his royal duties amid immense public criticism of their conversation, in which Andrew said he did not regret his relationship with Epstein.

According to Mahon (2003) lie is untruthful declaration. A person lies when they "give a believed-false declaration to another person for the purpose that the other person thinks the statement is true." The motives for undertaking this study are first, lying and deception theories have not been thoroughly researched in the linguistics field as the field of lying and deception commonly researched in philosophical theory (see Bok, 1978) Even though lying is considered as verbal act in which it has relation to linguistics (Jörg Meibauer, 2018b). Over the recent years linguistics has major research in lying and deception theories especially in pragmatics and forensic linguistics field. In 
pragmatics concept, one might argue that it is possible to lie even when they are telling the truth ( see Meibauer, 2005, 2011, 2018). Several features of linguistics also could be used as a tool for detecting deception in the interview. (Choudhury, 2014). Therefore, this study objective is to analyze Prince Andrew's interview using Grice's theory of Implicature (1975) and Bachenko's Deception theory (2008) to discover whether Prince Andrew's statements are deceptive in linguistics' perspective.

\section{Conversational Implicature}

Implicature designates simplifying something by saying something else or implicature is when the speaker indicates or implies with an utterance, although it is not communicated literally. Implicature is likely to help communicate effectively than just explicitly saying what people want to express, as Horn \& Ward (2006). Conversational implicature becomes one of the fundamental principles in pragmatics. The primary reasons why people do implicatures are to connect, to convey, and to record their thoughts. Such objectives can help to cooperate with or oppose others (Levinson, 2000).As P. Grice (1975) explained that conversational implicature occurs because their addressees are likely to communicate with people in order to comply with the maxims of conversation and the general principle of cooperation, which essentially states that people are required to interact in a cooperative, helpful manner. Thus, he made cooperative principle and four maxim of conversation.

The Maxim of Quality

Aim to make your contribution as true, namely:

- Do not say what you deem is false

- Do not say what you lack evidence of

The Maxim of Quantity

- Make your contribution informative as necessary

- Do not make your contribution more than necessary

The Maxim of Relation/Relevance

- Be relevant

The Maxim of Manner

Be clairvoyant, and specifically:

- avoid obscurity

- avoid ambiguities

- be brief (levitate undue prolixity)

- be orderly

Jörg Meibauer has expanded the analysis on deception using Grice's Implicature theory on the story taken from Posner (1980), The Story of Captain and The Mate (Meibauer, 2005). In his research Meibauer suggests that "lying is not only matter of what is said, but also what is implied" (Meibauer, 2005). The result of his analysis shows that even when the mate says the truth, he leads the reader into a false belief, that where on many other circumstances the captain must be intoxicated. On the basis of such 
instances, it is suggested that a general concept of lying needs to include deceptive implicature. They are planned by the speaker, despite being cancellable.

If their content is derived and believed by the hearers, they are deceived. The theory is in line with the theory of Total Significant Utterance (TSU) (H. P. Grice, 1989). In order to establish a conviction in the addressee that the speaker considers to be false, if a person knowingly violates a principle, this violation is perceived a case of deception, regardless of what is said is true at asemantic level (Willemsen \& Wiegmann, 2018).

\section{Bachenko's Theory Deceptive Markers}

The research on verbal deception demonstrates that distorted narrative at all levels, from global discourse to personal phrasing, can differ from true narrative. Narrative structure and length features, text continuity, factual and sensory information, occupied pauses, choice of syntactic structure, verbal spontaneity, negative statements, preliminary constructions, referential exclamations, and complex turns of phrase were all seen to distinguish true from deceptive statements in text. (Adams \& Boucouvalas, 2002)Bachenko et al., (2008) discovers many linguistic features that appear to be used by deceivers. In order to classify the language of deceivers, there are three key features used. The key features are 1) lack of commitment to a statement, and 2) preference for negative form which involves denial, words of negative emotion, lack of memory, 3) additional uncategorized markers of deception like other-oriented pronouns and references.

- Lack of commitment to a declaration

\section{Linguistics hedges}

Hedging applies to the use of specific words or mechanisms, often referred to as 'material mitigation,' implying a lack of complete commitment to an utterance (Fraser, 2010). The utterance full meaning is diminished. Hedging is perceived a deliberate act because 'the speaker selects a linguistic device that influences the meaning of the utterance over and above the propositional meaning of the message.' Hedging refers to the use of specific terms or structures, suggesting a lack of complete commitment to an utterance or commonly referred as 'content mitigation' or the intended illocutionary force of utterance (force mitigation) (Fraser, 2010).

Hedges are amongst the attributes that deceivers typically use to convey confusion or skepticism when they are in a communication. The deceivers also use hedges to conceal or prolong the truth. Although hedging is being done by the deceivers, they also try to violate the quantity maxim by not specifying the detailed information as requested. Hedges also could be used to avoid controversy, as according to Milanović \& Milanović (2010), hedging is a form of presenting a general statement in order to prevent commitment to one perspective and to demonstrate consistency.

Equivocation is defined as a form of linguistic hedges which does not directly respond to a question asked. From this point of view, equivocation is shown in the lack of clarification regarding one of the main elements of the process of communication. (Bavelas, Black, Nicole, \& Mullet, 1990) Equivocation as explained in Bachenko et al., (2008)is a method of speech implemented when the speaker seeks to avoid a direct answer to the questions but is disinclined to resort to outright lying, the outcome is at least to some degree a manner of speech intended to confuse dialogue rather than to 
gain clarification. Equivocation in political discourse has been used as a device for politicians to avoid challenging questions and the theory later become frequently used to assess how politicians interact with interviewer (Clementson, 2015), equivocation and deception are connected in oral narrative (Adams \& Boucouvalas, 2002), by using hedges repeatedly, the misunderstanding of the deceiver and interlocutor happened.

- preference for negative form

According to Bachenko et al., theory there are three types of negative form, the first one is denial words like do not, don't, or did not in frequent capacity. The second is negative quantifier or pronoun. These forms are referring to the words like 'nobody', 'impossible', 'nothing'. The third one is the negative form that shows doubtfulness. According to Makhfiana \& Himmawati (2017), the third one is negative morpheme, in which is a group of negative adjectives that express skepticism, such as unbelievable, unreliable, and unacceptable.

According to Shuy (1999), the sign of lack of memory also one of the sign of deception, especially in the interview or interrogation. The sign of memory loss in conversation for the example are 'I forgot', 'the next thing I remember', 'I don't remember'

- additional markers of deception

According to Hancock et al. (2008) another linguistics feature that can be used as markers of deception are sense words and other-oriented pronoun. In order to make the narrative seem more believable, deceivers are often more inclined to use sense expressions (for example, explaining touch, sound, smell, sight, and so on). Otheroriented pronoun is also deemed as marker of deception as deceivers use more second and third-person pronouns ('you,' 'she,' 'he,' 'they,' and 'their') to construct a 'otherfocus' and detach themselves from the lie (Hancock et al., 2008, p. 4).

\title{
METHOD
}

The study carried out using a qualitative approach. According to Dornyei (2007), Qualitative research includes data collection methods primarily resulting in open-ended, non-numerical data, which are further analyzed primarily through non-statistical methods. In other words, qualitative research is word related and non-statistical findings. The data collected from the full transcript of BBC Newsnight Interview from official $\mathrm{BBC}$ website, although the source of the transcript is full footage interview from BBC News broadcasting System that was broadcasted on November 15th 2019. Later the video was uploaded on November 17th 2019, and the duration of the videotape is 49 minutes, 26 seconds on Youtube. Since the data of this study is a transcript, a written record of a script of broadcasting program, the method is document analysis. Document analysis is a systematic procedure of document review or evaluation - both paper and digital (computer-based and internet-based) content. Like other analytical approaches of qualitative research, document analysis includes the evaluation and interpretation of data to obtain significance, comprehension, and empirical knowledge (Corbin \& Strauss, 2008)

\section{RESULTS AND DISCUSSION}

\section{Breaching Maxims of Conversation}

\author{
56 | ENGLISH EDUCATION
}

Journal of English Teaching and Research 


\section{- Maxim of Quantity}

1. EM: You said you weren't very good friends but would you describe him as a good friend, did you trust him?

PA: Yes, I think I probably did but again, I mean I don't go into a friendship looking for the wrong thing, if you understand what I mean. I'm an engaging person, I want to be able to engage, I want to find out, I want to learn and so you have to remember that I was transitioning out of the navy at the time and in the transition I wanted to find out more about what was going on because in the navy it's a pretty isolated business because you're out at sea the whole time and I was going to become the special representative for international trade and investment. So I wanted to know more about what was going on in the international business world and so that was another reason for going there. And the opportunities that I had to go to Wall Street and other places to learn whilst I was there were absolutely vital.

Above part of the conversation, Emily Maitlis asks Prince Andrew the confirmation about his relationship with Jeffrey Epstein, because, in his previous statement, Prince Andrew has described Jeffrey Epstein as close friends, she asked him with the question 'did you trust him?' Prince Andrew said yes, and he kept giving information that was not relevant to the question. For example, in the part when he is part of the navy and a special representative for international trade and investment, at this point, he was talking about his duty experiences rather than talking about Jeffrey Epstein.

According to Grice, the maxim of quantity requires a contribution that is as informative as necessary. If anyone produces more information than is necessary, it could be considered that he or she has violated the maximum quantity. The answer could have more compact and informative had it been. Prince Andrew does not say more than it requires. Based on Meibauer (2018), the violation of maxim of quantity creates 'lie by omission' in which the statement is a half-truth by purposely leaving or adding information in order to avoid truly answering the question. The truth about Jeffrey Epstein that Prince Andrew says is that Jeffrey Epstein is a very powerful man with a powerful connection. However, it is not the fully truthful statement, the most impactful statement, 'I don't go into a friendship looking for the wrong thing if you understand what I mean.' Meaning he deceptively implicates he had no problem with Jeffrey Epstein doing 'the wrong thing' as long as he got the benefits from befriending him and 'the wrong things' still come with it. The fact that he felt indifference about Jeffrey Epstein even though he was convicted as a sex offender and pedophile shows how 'acquaintance' he was to Jeffrey Epstein.

2. EM: So you're absolutely sure that you were at home on the 10th March?

PA: Yeah.

EM: She was very specific about that night, she described dancing with you.

PA: No.

EM: And you profusely sweating and that she went on to have bath possibly.

PA: There's a slight problem with the sweating because I have a peculiar medical condition which is that I don't sweat or I didn't sweat at the time and that was... was it...yes, I didn't sweat at the time because I had suffered what I would describe as an overdose of adrenalin in the Falkland's War when I was shot at and I simply... it was almost impossible for me to sweat. And it's only 
because I have done a number of things in the recent past that I am starting to be able to do that again. So I'm afraid to say that there'sa medical condition that says that I didn't do it so therefore...

Another example of a violation of maxim quantity based on too much information than what is required is displayed above. Emily Maitlis asked confirmation whether Prince Andrew was in his residence on the 10th March because, according to Virginia Roberts, he was not at home; instead, he met her and dancing together at Tramp. Later she continued that Prince Andrew was sweating so much that she had to take a bath. Prince Andrew's answer was rather long. He was describing his medical condition and why he could not sweat. This answer is deemed as unnecessary as he already claimed that he did not meet her at Tramp and dancing with her. When he said 'that I don't sweat or I didn't sweat at the time, and that was... was it... yes, I didn't sweat at the time', he implied that 'he didn't sweat back then and he still can't sweat right now in the interview.'

However, later he added, 'it was almost impossible for me to sweat. And it's only because I have done a number of things in the recent past that I am starting to be able to do that again' that implied that 'he can sweat now' contradicting with what he said at the beginning. In the closing of his answer, he concluded that he did not dance with her. He purposely added his statement that he could sweat now and conclude his statement to avoid the interviewer talking about his 'medical condition.'

\section{- Maxim of Quality}

Maxim of Quality is violated when the speaker is trying to make a contribution of utterance that is not true. The violation also can happen when the speaker is saying something that lacks evidence.

3. EM: I'm just trying to work this out because you said you went to break up the relationship and yet you stayed at that New York mansion several days. I'm wondering how long?

PA: But I was doing a number of other things while I was there.

EM: But you were staying at the house...

PA: Yes.

EM: ... of a convicted sex offender.

PA: It was a convenient place to stay. I mean I've gone through this in my mind so many times. At the end of the day, with a benefit of all the hindsight that one can have, it was definitely the wrong thing to do. But at the time I felt it was the honourable and right thing to do and I admit fully that my judgement was probably coloured by my tendency to be too honourable but that's just the way it is.

When the interviewer asked Prince Andrew about his visit to New York in 2010, two years after Jeffrey Epstein's arrest warrant, and yet, he was staying at Jeffrey Epstein's mansion. Emily Maitlis asks him how long he was staying at his mansion, Prince Andrew docked her question by saying that there are many things that he needed to do in New York, not just meeting with Jeffrey Epstein, Emily Maitlis reminds Prince Andrew again, the utmost importance topic of the conversation, which is why he was staying with the convicted sex offender, and Prince Andrew replies with 'convenient' place to stay, his answer could be seen as lying. It is common sense that New York, known as a state that is become one of the most popular tourist destinations. New York would not particularly be lacking in hotel rooms, especially with him as a distinguished guest. There is a 
privilege of being British Royalty, and it would be unlikely that hotel companies would refuse to accept a prince to stay in their hotel. This common sense would not fit Prince Andrew's (PA) statement; hence, he lied in this statement.

Moreover, most people would not call 'staying with sex offender' an honorable action and 'the right thing to do,' but he did, in fact, mentioned twice about him being 'honorable' and it was 'right thing to do.' He evaded the interviewer question on how long he was staying at Epstein's residence to cover up the fact that it is impossible for someone to stay for days just to talk about their 'breakup friendship', which means that he was trying to hide what kind of things he did within his stays at Jeffrey Epstein's.

4. EM: "Do you remember meeting her at all?"

PA: No."

EM: Do you know you didn't meet her or do you just not remember meeting her?

PA:_No, I have... I don't know if I've met her but no, I have no recollection of meeting her.

EM: Because she was very specific, she described the dance that you had together in Tramp. She described meeting you, she was a 17-year-old girl meeting a senior member of the Royal Family.

PA: It never happened.

EM: She provided a photo of the two of you together.

5. EM: "How do you explain that?"

PA: “I can't because I don't... I have no... again I have absolutely no memory of that photograph ever being taken."

EM: "Do you recognise yourself in the photo?"

PA: "Yes, it's pretty difficult not to recognise yourself."

EM: "Your friends suggested that the photo is fake."

PA: "I think it's... from the investigations that we've done, you can't prove whether or not that photograph is faked or not because it is a photograph of a photograph of a photograph. So it's very difficult to be able to prove it but I don't remember that photograph ever being taken."

EM: "But it's possible that it was you with your arm around her waist?"

PA: “That's me but whether that's my hand or whether that's the position I... but I don't... I have simply no recollection of the photograph ever being taken."

6. EM: "Just to clarify sorry, you think that photo has been faked?"

PA: "Nobody can prove whether or not that photograph has been doctored but I don't recollect that photograph ever being taken."

The contexts of three parts of the conversation (4 -6) are about the photograph of him and Virginia Roberts that was taken at Ghislaine Maxwell's party. When Emily Maitlis asked about the part where Prince Andrew met Virginia Roberts during a party at Ghislaine Maxwell's house, he denied the claim and stated that he did not remember ever meeting her. However, when he was asked about the evidence of the photograph by Maitlis, he answered it with hesitation as he said that it was uncertain whether the photograph was fake or real. The statement was contradicting with his previous 
answers because he said never met her before. Had he never met Virginia, he would not hesitate to make a claim that the photo never happened. Therefore, the photo is fake. There was two possible implication in this part of the conversation, the photo was fake, or Prince Andrew was lying. Throughout this part of the conversation, Prince Andrew's defense mechanism was only 'no recollection' of the event. The lack of evidence on Prince Andrew's part could be considered as a violation of maxim quality.

\section{- Maxim of Relevance}

The violation of Maxim of relation happens when the speaker provides a response that is irrelevant to the topic of conversation or the speaker purposely changes the topic from what is being talked about.

7. EM: "In 2008 he was convicted of soliciting and procuring a minor for prostitution, he was jailed, this was your friend, how did you feel about it?"

PA: "Well I ceased contact with him after I was aware that he was under investigation and that was later in 2006 and I wasn't in touch with him again until 2010. So just it was one of those things that somebody's going through that sort of thing well I'm terribly sorry I can't be... see you."

In this particular conversation (7), the interviewer, Emily Maitlis (EM), was asking about what he, Prince Andrew (PE), felt about his 'acquaintance,' Jeffrey Epstein after he was found guilty of minor sex trafficking. The answer should be straightforward how he felt about that happened; however, he diverted the question and told Maitlis he did not see him again when he was under investigation. This could be categorized as the violation of the relation maxim as Prince Andrew purposely changed the topic.

8. EM: "Yeah, I guess what I'm asking is do you feel that you were part of Epstein's public rehabilitation?"

PA: "Oh no, funnily enough I don't, no. I mean if he was... if he was doing... if that photograph was taken with that purpose in mind, then it doesn't... it doesn't equate to what actually happened."

The same kind of question (8) thrown again on how he felt about him being in Jeffrey Epstein's inner circles was thrown again later in the interview. Prince Andrew yet again evaded the question and told Emily Maitlis about the photograph. He did not state what he was feeling to be amid Jeffrey Epstein's scandals. Interestingly, he was evading any questions about what he felt concerning Jeffrey Epstein, except that he felt 'terrible' to not see him again. Based on the violation of relevance, it is shown that he did not feel remorse nor regret befriending Jeffrey Epstein.

\section{- Maxim of Manner}

Maxim of manner principles is orderly, brief, and unambiguous. To avoid a violation, the speakers are expected to state utterances that are not ambiguous and create confusion in conversation.

9. EM: Did you see him or speak to him again?

PA: No

EM: Never since then?

PA: No, that was... funny enough, 2010 was it, that was it because I went... well first of all I wanted to make sure that if I was going to go and see him, I had to make sure that there was enough time between his release because it wasn't 
something that I was going into in a hurry but I had to go and see him, I had to go and see him, I had to talk.

10. EM: And stay with him, and stay in the house of a convicted sex offender?

PA: I could easily have gone and stayed somewhere else but sheer convenience of being able to get a hold of the man was... I mean he was in and out all over the place. So getting him in one place for a period of time to actually have a long enough conversation to say look, these are the reasons why I'm not going to... and that happened on the walk.

Emily Maitlis was asking if Prince Andrew has reconnected with Jeffrey Epstein once again (9). Prince Andrew (PE) answered it with a much longer response after denying, but he later saw him and talked to Jeffrey Epstein. This statement was overused and created an equivocal statement. Later in the conversation (10), it is disclosed that he was meeting him and staying as a guest in Jeffrey Epstein's house by Emily Maitlis's statement, which is referring to the previous conversation (3). Prince Andrew created vagueness in his statement. He did not give a clear answer why he should stay to talk to Jeffrey Epstein, the answer given in 'sheer convenience of being able to get a hold of the man was... he was in and out all over the place' is abstruse and does not clarify anything other than he had to talk to Epstein. Therefore, this part of the conversation could be classified as a violation of the maxim manner.

\section{Linguistics Markers of Deception}

\section{- Equivocation that indicated deception within Violation as Lack of} Declaration within Statements

Table 1. Hedges used in the conversation

\begin{tabular}{|c|c|}
\hline Hedges/Equivocation & Examples \\
\hline Think & $\begin{array}{ll}\text { - } & \text { Yes }_{\llcorner} \text {I think } \\
\text { - } & \text { I think it's... from the investigations }\end{array}$ \\
\hline Probably & $\begin{array}{l}\text { - I probably did but again, } \\
\text { - } \quad \text { my judgement was probably coloured } \\
\text { by my tendency to be too honourable }\end{array}$ \\
\hline Mean & $\begin{array}{l}\text { - I mean I don't go into a friendship } \\
\text { looking for the wrong thing } \\
\text { - } \text { if you understand what I mean } \\
\text { - I mean he was in and out all over the } \\
\text { place }\end{array}$ \\
\hline
\end{tabular}

Prince Andrew appeared to use many hedges such as 'I think' as a lexical hedge, 'I probably' as the adverb hedges and proceed to use it quite a bit of time. This frequent use of hedges suggests the absence of the desired conversation; as it becomes evasive, it is clearly evident that he was not in favor of answering it, but he answers the question nonetheless with many hedges as fillers. The lexical hedges appeared as speakers are looking for the next impending words to convey. They are also employed as a tool for stalling the conversation intervals. Lexical hedges also have a function as a repair and explanation signals of the words of lexical hedges in the medial position. The adverb hedges also appear in the conversation. Based on the interview, Prince Andrew used 
adverb hedges like 'probably' to use as the tool to ease doubt and raise credibility in the conversation. The frequent use of hedges in the interview exhibits the lack of commitment to the true value and absence of the appeal to express the interviewer's question, which could imply hiding something as Lakoff(1973)stated, "a number of linguistic features which were unified by their function of expressing lack of confidence or showing the expression of uncertainty or tentativeness."

- Preference of Negation Expression in Violation of Maxims a. Negation Form

Table 2. Negative expression within the conversation

\begin{tabular}{|c|c|}
\hline $\begin{array}{l}\text { Negation } \\
\text { Form }\end{array}$ & Example \\
\hline $\begin{array}{l}\text { Contracted } \\
\text { Negation }\end{array}$ & $\begin{array}{l}\text { - I don't go into a friendship looking for wrong } \\
\text { things } \\
\text { - I don't recollect that photograph ever being } \\
\text { taken. } \\
\text { - I don't remember that photograph ever } \\
\text { being taken. } \\
\text { - I don't sweat or I didn't sweat at the time } \\
\text { - I don't know if I've met her but no } \\
\text { - you can't prove whether or not that } \\
\text { photograph is faked }\end{array}$ \\
\hline $\begin{array}{l}\text { Negative } \\
\text { Quantifier } \\
\text { Negative } \\
\text { Morpheme }\end{array}$ & $\begin{array}{l}\text { - Nobody can prove whether or not that } \\
\text { photograph } \\
\text { - } \text { it was almost impossible for me to sweat }\end{array}$ \\
\hline
\end{tabular}

Based on table 2 above, Prince Andrew used contracted negation numerous times. The strings of negation appear strongly when he tried to deny the relationship between him and Virginia Roberts and the existance of the photograph taken in Ghislaine Maxwell's house. Negative quantifier appears also when the interviewer asked about the validity of the photograph. Negative morpheme turns up also when he was asked about his meeting and dancing event.

\section{b. Lack of Memory as Indication of Deception}

The indication of lack of memory being displayed in the conversation was numerous. The most evident lack of memory Prince Andrew said during the interview was categorized into 3 forms. These examples were taken from the discussion of violation of maxim quality.

Table 3. the lack of memory being displayed in conversation

\begin{tabular}{|c|c|}
\hline $\begin{array}{l}\text { Lack of Memory } \\
\text { Indication }\end{array}$ & Examples \\
\hline No recollection & 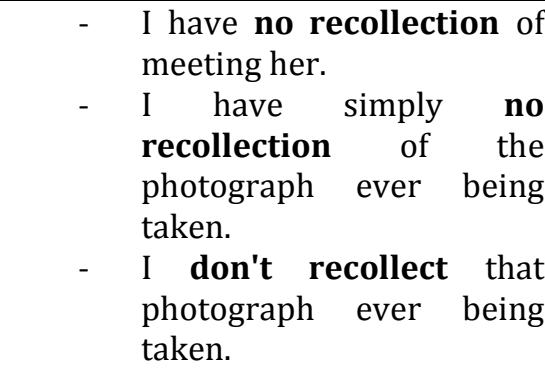 \\
\hline
\end{tabular}

No memory - I have absolutely no 


\begin{tabular}{llr} 
& $\begin{array}{l}\text { memory of that } \\
\text { photograph ever being } \\
\text { taken. }\end{array}$ \\
Don't remember & $\begin{array}{l}\text { I don't remember that } \\
\text { photograph ever being } \\
\text { taken. }\end{array}$ \\
\hline
\end{tabular}

\section{- Additional Deception Marker of Deception}

The additional deception markers are used to detect some deception are sense words and other-oriented pronoun and references.

\section{a. Sense words}

The usage of sensory words is more likely used by deceivers to enhance detail and appeal to the narrative. (Hancock et al., 2008) Prince Andrew used a few sense words because he was not describing an event or chronology in detail when he violates the maxim of manner. He appeared to use sense words like 'see' and 'look' multiple times within the same context.

\section{b. Other-oriented pronoun and references}

The lesser use of other-oriented pronouns was not supported by this study because Prince Andrew used the first-oriented pronoun more often than the other-oriented pronoun. The reason is likely the same as the explanation on his fewer use of sense words. The use of first-person oriented mostly appears when he violated maxim of quantity and quality. In quantity, he violated by giving information more than it required. The flux of I in maxim quantity appeared when he was looking for justification. For example, 'I'm an engaging person,' 'I was going to become the special representative,' and 'I was shot at and I simply... it was almost impossible for me to sweat.' The second flux of the first-oriented person is when he violated the maxim of quality. The obtuse amount of ' $\mathrm{I}$ ' appeared when he asked why he stayed at Jeffrey Epstein's house, and his refute of his meeting with Virginia Roberts.

\section{CONCLUSION}

As clarified in the discussion and having examined and analyzed maxim violations and linguistic marker of deception, both of these theories are useful to identify some parts of a conversation that deemed deceptive. Violation of maxims could be useful to understand the context within the interview and beyond what it said during the interview. Meanwhile, linguistics markers of deception could be useful to identify what kind of words that Prince Andrew's said during the interview. As a result, Prince Andrew appeared to violate four maxims of conversation. The most evident deception could be seen in the violation of maxim quantity, quality, and manner as these parts of conversation appear to mislead the listener to conceal the truth, for instance, when he said 'I don't go into a friendship looking for the wrong thing' to conceal the fact that Prince Andrew had been befriending with Jeffrey Epstein when he was convicted as a sex offender. The analysis of linguistic markers of deception also shown that many deception indications associated with Prince Andrew's conversation, namely lack of commitment in the declaration, preference of using negative expressions, and lack of memory. However, there were a few occasions where the result contradicted the previous research in consideration of the type of interview. 
Further research and investigation are needed to improve and support the theories. It is noted that this study is against generalizing from the findings of the study and data as the result of interview analysis depends on the context and duration of a conversation. Future studies in this field could expand by using the interview method instead of nonparticipant observation to broaden the findings.

\section{REFERENCES}

Adams, S. H., \& Boucouvalas, M. (2002). Communication Under Stress:Indicators of Veracity and Deception in Written Narratives.

Bachenko, J., Fitzpatrick, E., \& Schonwetter, M. (2008). Verification and implementation of language-based deception indicators in civil and criminal narratives. Coling 2008 - 22nd International Conference on Computational Linguistics, Proceedings of the Conference, 1(August), 41-48. https://doi.org/10.3115/1599081.1599087

Bavelas, J. B., Black, A., Nicole, C., \& Mullet, J. (1990). Truths, Lies, and Equivocations: The Effects of Conflicting Goals on Discourse. SAGE Journal of Language and Social Psychology, 9(1), 135-161. https://doi.org/https://doi.org/10.1177/0261927X9091008

Bok, S. (1978). Lying: Moral Choice In Public. Retrieved from http://repositorio.unan.edu.ni/2986/1/5624.pdf

Choudhury, F. (2014). Can Language Be Useful in Detecting Deception? The Linguistic Markers of Deception in the Jodi Arias Interview. Diffusion- The UCLan Journal of Undergraduate Research, 7(2), 78-92. Retrieved from http://bcur.org/journals/index.php/Diffusion/article/view/16

Clementson, D. E. (2015). Why Do We Think Politicians Are So Evasive? Insight From Theories of Equivocation and Deception, With a Content Analysis of U.S. Presidential Debates, 1996-2012. Journal of Language and Social Psychology, 35(3), 247-267. https://doi.org/10.1177/0261927X15600732

Corbin, J., \& Strauss, A. (2008). Basics of Qualitative Research (3rd ed.): Techniques and Procedures for Developing Grounded Theory. https://doi.org/10.4135/9781452230153

Fraser, B. (2010). H Edging. 1-2.

Grice, H. P. (1989). Studies in the Way of Word. Harvard University Press.

Grice, P. (1975). Logic of Conversation. The Semantics-Pragmatics Boundry in Philosophy, pp. 41-58.

Hancock, J. T., Curry, L. E., Goorha, S., Woodworth, M., Hancock, J. T., Curry, L. E., ... Woodworth, M. (2008). On Lying and Being Lied To : A Linguistic Analysis of Deception in Computer-Mediated Communication On Lying and Being Lied To : A Linguistic Analysis of Deception in Computer-Mediated Communication. 6950(March), 37-41.

Horn, L., \& Ward, G. (2006). The Handbook of Pragmatics.

Lakoff, G. (1973). Hedges: A study in meaning criteria and the logic of fuzzy concepts. Journal of Philosophical Logic, 2(4), 458-508. https://doi.org/10.1007/BF00262952

Levinson, C. S. (2000). Presumptive Meanings: The Theory of Generalized Conversational Implicature. https://doi.org/10.11435/gengo1939.2001.120_131

Mahon, J. E. (2003). Kant on lies, candour and reticence. In Kantian Review (Vol. 7). https://doi.org/10.1017/S1369415400001758

Makhfiana, L., \& Himmawati, D. R. (2017). DECEPTION ANALYSIS OF CHUTNEY 
WINDHAM IN LEGALLY BLONDE MOVIE. 05, 66-73.

Meibauer, Jöorg. (2011). On lying: Intentionality, implicature, and imprecision. Intercultural Pragmatics, 8(2), 277-292. https://doi.org/10.1515/IPRG.2011.013 Meibauer, Jörg. (2005). Lying and falsely implicating. Journal of Pragmatics, 37(9 SPEC. ISS.), 1373-1399. https://doi.org/10.1016/j.pragma.2004.12.007

Meibauer, Jörg. (2018a). Introduction. In Jörg Meibauer (Ed.), The Oxford Handbook of Lying (pp. xxiv-10). https://doi.org/10.1093/oxfordhb/9780198736578.013.1

Meibauer, Jörg. (2018b). The Linguistics of Lying. Annual Review of Linguistics, 4(1), 357-375. https://doi.org/10.1146/annurev-linguistics-011817-045634

Milanović, M., \& Milanović, A. (2010). SOFTENING THE WORDS OF CRISIS : HEDGING IN ECONOMICS. 4(1), 121-129.

Shuy, R. W. (1999). The language of confession, interrogation and deception. Thousand Oaks: Sage.

Willemsen, P., \& Wiegmann, A. (2018). How the truth can make a great lie: An empirical investigation of the folk concept of lying by falsely implicating. CogSci, (August), 3516-3521. Retrieved from https://www.pascalewillemsen.com/wpcontent/uploads/2017/12/Wiegmann-Willemsen_How-the-truth-can-make-agreat-lie.pdf

\section{Data Sources}

Bbcnews. (2019, November 17). Prince Andrew \& the EPSTEIN scandal: The Newsnight interview - BBC News. Retrieved March 18, 2021, from https://www.youtube.com/watch?v=QtBS8COhhhM

Prince Andrew Newsnight interview: Transcript in full. (2019, November 17). Retrieved March 18, 2021, from https://www.bbc.com/news/uk-50449339 